\title{
Young Representatives of Ethnic Communities: Sociocultural Strategies and Practices
}

\author{
Tatiana Titova \\ Kazan (Volga Region) Federal University, Institute of International Relations, \\ History and Oriental Studies, Russian Federation \\ Email: tatiana.titova@rambler.ru \\ Vadim Kozlov \\ Kazan (Volga Region) Federal University, Institute of International Relations, \\ History and Oriental Studies, Russian Federation \\ vadim.kozlov@list.ru
}

\section{Elena Gushchina}

Kazan (Volga Region) Federal University, Institute of International Relations, istory and Oriental Studies, Russian Federation egguschina@mail.ru

\section{Maria Vyatchina}

Kazan (Volga Region) Federal University, Institute of International Relations, History and Oriental Studies, Russian Federation maria.vyatchina@gmail.com

\section{Doi:10.5901/mjss.2015.v6n3s2p287}

\section{Abstract}

The article deals with the analysis of the sociocultural identity, linguistic and cultural attitudes, and intragroup solidarity of the young representatives of the Uzbek, Tajik and Azerbaijan people in the Republic of Tatarstan. Religion is considered as an ethnointegrating characteristic, determining and influencing the sociocultural strategies and practices of the diaspora youth. The results presented in the article are based upon the materials obtained by the authors during the period from April to June 2013 on the territory of the Republic of Tatarstan.

Keywords: interethnic relationship, ethnic minorities, labour migration, discrimination, identity, ethnic majority, interethnic solidarity.

\section{Introduction}

Nowadays migration is an integral part of social and economic processes, and these processes are in constant conditions of changes. For instance, for the last 15-20 years several changes of labour migrants' countries occurred (the offset of migration from the Caucasus to Central Asia). According to S. Abashin, it not only increases the number of groups participating in migration, but also involves new social groups, for example the representatives of small business and the intelligentsia. Gradual involvement of women and participation of children and other family members should also be mentioned. A generation of children grown up here is appearing, the territorial expansion of the described processes is taking place. "All these processes are developing, and they depend on various factors which may influence the situation as it used to be during the crisis of 2008-2009 and in the way it may be in case of the visa regime introduction with the countries of Central Asia" (Abashin, 2012).

During the last decades of the XXth century the liberal western community declared a problem of ethnic minorities to be a social problem of discrimination (Simon, 2012). In Russian regions this problem is being put forward. As a rule, the title nations of the constituent territories of the Federation and the Russians living there have been the targets of recent scientific research until recently. The peculiarities of relationship of these groups within the regional community have been the subject of research (Stolyarova , 2004). The tendency of recent years is the rise of tension connected with the ethnic majority which comprises the title nations and the Russians of a region and with the groups of ethnic minorities 
which play increasingly significant role in the social and economic life of regions. Tatarstan is not an exception. Frequent displays of intolerance to the representatives of ethnic minorities prove that. Despite the fact that the bulk of these displays have the declarative or latent character, real manifestations of xenophobia also occur (Titova \& Kozlov \& Kushaev \& Dzhaksybaev, 2010). The study of the young people of the ethnic groups is currently important. Firstly, the young people are aimed at the permanent place of residence among the host population more often than the representatives of the middle and older age groups. Secondly, the conveience of the regional background in general depends on the degree of their integratedness into the social, economic and cultural, including the ethocultural, environment.

\section{Methods}

The multi-paradigm approach was used as a basic one for the investigation of the problem (Drobizheva , 2006). I was complemented by certain points of the Nationalism studies (Gellner, 2009; Hobsbawn, 1983), socialisation (Berger \& Lukman, 1966; Barth, 1989), regional approach to the study of minorities, being in the environment belonging to another nation (Titova, 2007).

The research is built on the combination of the quantitative (ethnic surveys) and qualitative methods (depth interviews, focus groups, expert interviews). The empirical data accumulated by the authors for the period from April to June 2013 in the Republic of Tatarstan serves the source base of the research (200 Uzbeks, 150 Tajiks, 150 Azerbaijanis were interviewed). The snow-ball method was used for the selection. The fusion of data obtained with the quantitative and qualitative methods aims at many-faceted studying of the subject of the study, possibility of appealing to the context of the situation, and seeing the percent indices of the expansion of this phenomenon and its assessment by the interviewees. The choice of the three concrete groups was justified by the necessity of the comparison by such characteristics as the country of origin and belonging to different waves of migration. Using the results of the survey we are aimed, mainly, at finding out the tendencies, but not at concrete figures, which may be distorted by different factors, including the selection bias. Furthermore, the data obtained by the depth interviews allows to deepen knowledge of every issue and demonstrate the significant factors concerning individual migration status.

Various institutions study migration in the modern scientific and educational environment in different paradigms and with different purposes. It is possible to consider a detailed study of a specific focus (the religious factor of migration (Yusupova, 2013; Starostin, 2012; Khalid, 2007), the gender aspect, the ethnocultural development (Vitkovskaya, 2000), the legal status (Ryazantsev \& Khorie, 2011; Levitt \& Deepak, 2011; Brubaker, 2010; Zaionchkovskaya \& Molodikova \& Mukomel, 2007; Massey \& Arango, 1993), and pay attention to significant summarizing works in the given sphere (Migratsiya $\vee$ Rossii , 2013). It is important that migration is viewed by the scholars on a much larger scale than, for example, a decade ago. It concerns not only the quantitative increase of the number of experts in migration study, but is also connected with the focus for the analysis of the new social processes accompanying the development of transnationality.

\section{Results}

The first place in the structure of the social identity of the Uzbeks belongs to the status characteristics (a person, individual, citizen, etc.); the gender and family roles are on the second place, the professional characteristics are on the third place. The ethnic identity is on the last place - it was mentioned by less than $5 \%$ of respondents.

While analysing the actualised self-definitions of the surveyed Tajiks it was found out that there are more subjective characteristics than the objective ones in their identification matrix: the subjective personal characteristics (kind, beautiful, clever, etc.) are on the first place in the structure of identity - they were mentioned by every second surveyed Tajik. The professional and status characteristics are essential for a quarter of respondents. As well as the Uzbek respondents, less than $5 \%$ of the Tajik respondents pointed out that the ethnic identity is significant.

Predominance of subjective characteristics in the structure of social identity may be evidence of the fact that the respondents can hardly identify themselves in the context of social relationships and are poorly integrated into the host society.

The analysis of social contacts, linguistic and cultural attitudes of the respondents proves this assumption. For example, despite the fact that in total more than a quarter of the respondents, the vast majority of whom are young people under 25 , say that they have friends among the local population (mainly among the Tatars), the vast majority (more than 90\%) of the Uzbeks and the Tajiks and two-thirds of the Azerbaijanis in all the age groups maintain closer friendly relationships with the representatives of their nation. This fact may be interpreted as a consequence of 
maintaining relative and fellow-countrymen relationships.

The majority (more than 90\%) of the Azerbaijanis and Tajiks consider their national language to be their native one. This index is higher among the Uzbeks - the Uzbek language is considered as a native one by almost all the respondents.

The majority of the respondents declare that they have mastered the Russian language to a greater or lesser degree. However, the representatives of the studied groups have different levels of language competence. Most of the Azerbaijanis and two-thirds of the surveyed Tajiks say about fluency of the Russian language ("I speak, read and write fluently'), while three-fourths of the surveyed Uzbeks know the Russian language at the level of colloquial speech. Every second Azerbaijani and one in three Tajiks know the Tatar language at the level of colloquial speech. Every second Uzbek comprehends the Tatar language.

The level of their linguistic and cultural competence is especially highly assessed by the young respondents under 25. The desire to improve their knowledge of the Russian and Tatar languages is typical of this age group. As the realia of the countries of their origin demonstrate another situation (the youth brought up in the post-Soviet time do not have the knowledge of the language which the Soviet generations have - primarily, men who served in the Soviet army, the intelligentsia, etc.), they are likely to be the consequence of the age psychological peculiarities of self-identification in the world order view.

The least degree of readiness to improve their knowledge of the Russian language was expressed by the Azerbaijanis, one-third of whom do not want or consider it necessary to do anything for it, thinking that they have mastered the Russian language well enough. Many of the representatives of the Azerbaijani diaspora emphasise that the Russian language plays a large role in their life and has become their "second native" language: "Azerbaijani is my native language, and Russian has become my second native language. My sister speaks Azerbaijani to me, but I answer in Russian" (on materials of open questions of questionnaires, man, 26 years).

Every second Tajik declares their readiness to do their best to improve their knowledge of Russian; two-thirds of the Uzbeks express their wish to study the Russian language, but they say that they do not have such an opportunity. In spite of the fact that the Uzbek respondents actively express their wish to study the Russian language, they do not take pains to succeed. The Uzbeks taking part in the focus groups spoke about a variety of problems facing them both in professional sphere and everyday life because of the language barrier: "Some workers don't understand, it is hard to explain to them... sometimes you can't explain neither in Russian, nor in Tatar" (on materials of open questions of questionnaires, man, 27 years).

In general, men are aimed at the improvement of their linguistic competence more than women. It may be proved by the conclusion made in our previous research among diasporas and migrant communities, according to which men have more opportunities and necessities to adapt to the host society, and women confine themselves to their ethnic groups: "According to the customs, a wife should stay at home bringing up children" (on materials of open questions of questionnaires, man, 25 years). At the same time, our interpretation is based on heterogeneous data and aimed at distinguishing trends. We should say that in some cases gender disposition is of another kind, and women less involved in the social net of migrants which is formed of several group identities (for example, territorial closeness, kinship) and marginal ones in their social status (divorced, being in interethnic marriage, single mothers) turn to be more successful in the strategies of integration into the host population. The professional sphere, for example a necessity to communicate with people, encourages their involvement, (which is especially typical in the sphere of trade or retail food).

Undoubtedly, we cannot cast doubt on the facts of correspondence of language competence marked in the questionnaires to the international standards of language knowledge. However, it is not viewed as a target. Analysing any behaviour it is important to remember of the effects described by the Thomas theorem: if a person considers a situation to be real, it will be real in its consequences. Therefore, if a respondent marks this or that option, they are likely to have some reasons to make a researcher / observer perceive them by the image they create in the answers of the questionnaire.

The research has showed correlations between sociodemographic characteristics of the respondents and their positions. For example, the ethnic and religious identity is of great importance for young people under 25 - they mention these aspects of identity half again as the respondents of an older age; but the gender, family, status and professional characteristics are more essential for the representatives of young and middle age groups (between 25 and 50). The status and professional identity is more important for men; the family and gender identity is more essential for women.

The ethnointegrating characteristics, such as "origin" and "language" is of great importance for the respondents, which is evidence to the traditional perception of the ethnicity as a group, mainly united by the common language, territory and origin, i.e. "the call of the blood". Religion plays a great role in the respondents' ideas about what unites them with other people of their nation. Considering religion as an ethnointegrating feature is especially typical of the Uzbeks. 
Every second respondent among the representatives of the Azerbaijani diaspora and one in three Tajiks emphasised the importance of religion.

For the majority of representatives of the studied groups the fact that Tatarstan is perceived in their native countries as a Muslim republic was a decisive factor when making a decision about leaving. The respondents characterise the interethnic climate in the republic as convenient: "We feel good in Tatarstan, it isn't so good everywhere and everything corresponds to the religion"; "Since the first day I have felt that I got to the second motherland, because Tatarstan and Azerbaijan have much in common". (on materials of open questions of questionnaires, man, 26 years)

One third of the respondents in all the studied groups confess that they have problems in communication with the local population. The Tajiks and the Uzbeks see the reasons of this fact in their bad knowledge of the language and in their ethnic background: "They say that if people came from Tajikistan, they are illiterate, terrorists, and sell drugs" (on materials of open questions of questionnaires, man, 27 years). The Azerbaijanis see the reason of difficulties in their own psychological peculiarities and those of local population. Previous research among the local population concerning their attitude to the migrant communities showed that the population of the republic, while explaining their negative attitude to the migrants, mention the same reasons: lack of language knowledge, unwillingness to adapt and lack of knowledge about the culture, traditions peculiarities of psychology and mentality of the representatives of these peoples. Correspondence of opinions which prevent from integration and acceptance, allows to speak about potential opportunities of development of successful scenarios for overcoming barriers between migrants and host population if such a task is set at the level of district administration or the federal centre and nonprofit organisations.

The informants who have recently come to the Republic say that the individualism of the local population and poor expressiveness of the collectivist spirit prevent their adaptation: "We have a habit to be guests at somebody's place, always, without any reason. We make friends with our neighbours. Everyone in our house knows each other. Here I don't even know my neighbours, those who live next to me. For example, when we cook pilaf, we treat our neighbours. And they stare at us with surprise. This astonishment is unpleasant" (on materials of open questions of questionnaires, man, 24 years). This is probably a communication mistake (at the level of behavior rather than that of speech), caused by the difference of social experiences of migrants and those of their new/local neighbours. Moreover, the young people have such interaction, especially in the situation of the first migration, which may be considered as the effect of the first and the most superficial impressions, and this opinion may be changed in the future.

Answering the question about what an impression the daily life of the local population makes on them, the informants mention several characteristics which they find negative: "In our country (In Tajikistan) both Tatars and Tajiks are hospitable. I have also visited many celebrations here. But I didn't like the children's attitude to their parents. They consider themselves to be free, they don't obey their parents. They speak in a gross manner. It is necessary to respect parents who have brought you up"; "There are no smoking girls in Uzbekistan, but it is a problem in your country" (on materials of open questions of questionnaires, man, 28 years).

Two-thirds of the interviewed Azerbaijanis and Uzbeks and one in two Tajiks say that they have friends among the local population, primarily among the Tatars: "The Tatars are mentally closer to me. The Russian people have another attitude to foreigners. They communicate rarely, they are not so hospitable. But the Tatars are hospitable, and it is easier to find a common language" (on materials of open questions of questionnaires, man, 26 years). In this situation it is of great importance to understand what a respondent means by the category "friends", what kind of social relationships are supposed to exist for referring a person to this group at the individual level.

In all the studied groups the respondents demonstrate quite a high level of intragroup unity, which is indirect indicator of a low degree of readiness for interethnic relationship. It primarily concerns the Azerbaijani respondents. Lack of social interaction with the local population is mainly caused by the language barrier. One in ten Azerbajani, one third of Tajiks, and three-fourths of Uzbeks say that they spend their free time communicating with their fellow-countrymen. Intragroup unity is a compensatory mechanism for overcoming the consequences of unsuccessful scenarios of interaction with employers and host population, who have a tendency to develop their own algorithms of problem situations solution.

The respondents tend to be aimed at monoethnic marriages: "Even if you live in another country, it is undesirable to mix the blood. The same language, the same traditions."; "There is an opinion that one's own nationality is above anything else, the others are thought to be of the second rate. And it is considered that it is better to marry those of your nation than those of a foreign one. An the Azerbaijanis have such a peculiarity - to marry their relatives..." (on materials of open questions of questionnaires, man, 23-24 years). This fact is additional evidence that the situation of the labour migration suggests different opportunities for the young people, including options in the choice of marriage partners.

The majority of the surveyed people in all the studied groups are married to the people of the same nation. Twothirds of the surveyed Uzbeks, one third of the Azerbaijanis and one in ten Tajik declared that they would disapprovingly treat a marriage of their relative with a representative of another nation. Men and women in younger and middle age 
groups are more categorical on this question, which may be explained by much less social experience than that possessed by the older generations. It accepts various life scenarios, including an interethnic marriage: "We try to avoid a marriage with local girls. My brothers and nephews are not married, they work here, and I will do my best so that they will not marry. Their parents also asked me to prevent them from finding fiancées here" (on materials of open questions of questionnaires, man, 26 years).

Young respondents under 25 are less categorical and they accept marrying to representatives of other nations. However, they realise that such a scenario is unlikely, as "in these cases parents make all the decisions, and everything will be as they say"; "Parents found a fiancée for me, I didn't even know" (on materials of open questions of questionnaires, man, 23 years).

A marriage with a representative of the same nation in a native country is a preferred scenario of the family life. The Uzbek respondents were particular about it: "You know, I have a daughter, she is 18, if she speaks to any young man, I will kill her myself. We have strict rules about that. And when parents of a would-be husband come, we will see what kind of family it is, if a young man is good or not. If we don't like the family, I will say "no", even if my daughter likes them, she can't say "yes". She will marry a man who I will marry her to" (on materials of open questions of questionnaires, man, 26 years).

As an exception, girls representing other ethnic groups must be Muslims or convert to Islam: "A wedding ceremony is secondary for us. At first, we have the Nikah (Muslim marriage rite). And for this it is necessary for both sides to be Muslims" (on materials of open questions of questionnaires, man, 24 years).

Converting to Islam is welcomed and considered to be positive and correct as well as wearing a hijab. It was emphasised by the Tajik respondents taking part in focus groups: "I would like my wife and daughter to wear hijabs. There is nothing bad in it. The hijab points at a woman's modesty and decency" (on materials of focus groups, man, 24 years). In spite of the strict requirements of the community for the religious aspect of the marriage, it may be viewed as an indicator of the traditional character of marriage and an element of a celebration ritual of any culture rather than a consequence of the religious fundamentalism.

Some representatives of the studied communities, primarily the Tajiks, practice polygamy, which is caused by Islam and life experiences: "Many people live with their families here. Some people have married here - they have a second wife" (on materials of open questions of questionnaires, man, 26 years).

Polygamy as a social phenomenon is also spread among the Azerbaijanis: "There is a conception of two wives, one of them lives there, another one - here. $90 \%$ of the Azerbaijanis live this way. As a rule, wives in their countries don't know about their existence. It is typical of people over 30, who are already married. Therefore, men are independent and can provide for both of them. Moreover, they spend much time here, rarely visiting their motherland. It is convenient for everyone. Many Azerbaijanis have Russian wives. There is a conception of two citizenships. He gets a clear passport here and can marry here according to the law" (on materials of open questions of questionnaires, man, 28 years).

The economic causes of polygamy, alongside the basis of Sharia, turn out to be not only characteristics of the phenomenon. The connection of migration and polygamy may be considered at least in two different aspects: polygamy in the Muslim context and the cases of marriage in the host country (not necessarily registered in a secular or religious institution, but necessarily implying the economic unity and common housekeeping), in spite of the fact that there is a wife in their native country. This phenomenon (in the present-day scale) may be considered to be quite new and it is to be scientifically described and analysed.

\section{Discussion}

The structure of the social identity and the linguistic and cultural behaviour of the young representatives of diasporas is evidence of their poor integratedness into the host society. Among all the studied groups the Azerbaijanis demonstrate a better variety of social characteristics, pointing at their successful integration into the host society. They are also characterised by the significance of ethnic identity. It is found out that the Tajiks and the Uzbeks have fewer characteristics, there are more subjective characteristics than objective ones in the structure of social identity, which is evidence of the problems in adaptation and poor integration into the host society.

Men are aimed at the improvement of their linguistic competence more than women, which proves that men have more opportunities and necessities to adapt to the host society; and women confine themselves to their ethnic groups. It also can be proved by the fact that the status and professional identity is more important for men; the family and gender identity is more essential for women.

Individual barriers of the interethnic relationship are observed in all the studied groups. Poor knowledge of the language is a barrier for the Tajiks and the Uzbeks. The Azerbaijanis demonstrate a high level of intragroup unity, which 
prevents from their integration into the host society. The surveyed people are emphatically aimed at monoethnic marriages; the Uzbeks are particular about their disapproval of interethnic marriages.

\section{Conclusion}

1. The research of the respondents' social identity structure shows that the ethnic and religious identities are of great importance for the young people under 25. The gender, family, status and professional characteristics are more important for the representatives of the young and middle age groups.

2. The problems of adaptation are reflected in the linguistic and cultural processes in the environment of the studied communities. The Uzbeks are the worst at the Russian language (problems appear the level of understanding the colloquial speech). The Tajiks and the Azerbaijanis more highly assess their linguistic and cultural competence. Despite the fact that the respondents express their wish to improve their knowledge of Russian, these statements have only the declarative character.

3. In spite of the generally convenient interethnic climate in the republic mentioned by the respondents, the majority of them are not aimed at the interethnic interaction.

4. The analysis of the obtained data proves that the majority of the respondents do not make efforts to integrate into the host society: lack of intention to improve their knowledge of the Russian language and the existent reluctance to leave the boundaries of their ethnic community are the evidence of that.

\section{References}

Abashin, S. (2012). Sredneaziatskaya migratsyia: praktiki, localnyie soobshchestva, transnatsyonalizm. Etnograficheskoye obozreniye. 2012. \# 4. P. 3-13.

Simon, T.W. (2012). Ethnic Identity and Minority Protection: Designation, Discrimination, and Brutalization. Published by Rowman and Littlefield Publishers, pp: 330.

Stolyarova, G.R. (2004). Fenomen mezhetnicheskogo vzaimodeistviya: opyt postsovetskogo Tatarstana. Kazan, Kazan State University. $315 \mathrm{p}$.

Titova, T.A., Kozlov, V.E., Kushaev, R.R., Dzhaksybaev, S.K. (2010). Etnicheskiye menshinstva v Tatarstane: teorii, strategii i praktiki mezhetnicheskogo vzaimodeistviya. Ed. by T.A. Titova. Kazan: Intelpress+. 266 p.

Drobizheva, L.M. (2006). Metodologicheskiye problemy etnosotsiologicheskikh issledovaniy. Sociological Journal. 2006. № 3-4. P. 89101.

Gellner, E. (2009). Nations and Nationalism. Cornell University Press, pp: 152.

Hobsbawn, E. (1983). Invention of Tradition. Cambridge University Press, pp: 320.

Berger, P.L. Lukman, T. (1995). The Social Construction of Reality: A Treatise on the Sociology of Knowledge. Academia-Center-Media, pp: 323.

Barth, F. (1989). Analysis of Culture in Complex Societies. Ethnos, 4: 120-142.

Titova, T.A. (2007). Etnicheskiye menshinstva v Tatarstane: status, identichnost, kultura. Kazan, Kazan State University, 2007. 254 p.

Yusupova, G. (2013). The Influence of Islam on Social Networks of Low-Skilled Migrants from Central Asia to Russia // MPC AS 2013/01, Robert Schuman Centre for Advanced Studies, San Domenico di Fiesole (FI): European University Institute. 2013. 11 p.

Starostin, A. «Islamskiy faktor» v migratsionnykh protsessakh v Rossii. 12 April 2012. URL: http://russiancouncil.rulinner/?id_4=298 (accessed 12 April 2014).

Khalid, A. (2007). Islam after Communism: Religion and Politics in Central Asia. Berkeley; University of California Press, 2007. 234 p.

Migratsiya i bezopasnost v Rossii (2000). Carnegie Moscow Center. Ed. by G. Vitkovskaya, S. Panarin. Moscow: Interdialekt+, 2000. $341 p$.

Ryazantsev, S.V., Khorie, N. (2011). Modelirovaniye potokov trudovoy migratsii iz stran Tsentralnoy Azii v Rossiyu. Ekonomikosotsiologitcheskoye issledovaniye. - Moscow: Nauchnyi mir. $192 \mathrm{p}$.

Levitt, P., Deepak L.-N. (2011). Social remittances revisited. Journal of Ethnic and Migration Studies. \#1 (37). 2011. P. 1-22.

Brubaker, R. (2010). Migration, membership, and the modern nation-state: Internal and external dimensions of the politics of belonging. Journal of Interdisciplinary History. 2010. T. 41. \# 1. P. 61-78.

Zaionchkovskaya, Zh. A., Molodikova, I., Mukomel V. (2007). Metodologiya i metody izucheniya migratsionnykh protsessov: multidisciplinary textbook. Moscow: Centre of Migration Research. 370 p.

Massey, D., Arango, J. and others. Theories of International Migration: a review and appraisal. Population and Development Review. Vol. 19. \# 3. P. 448-450.

Migratsiya v Rossii 2000-2012. (2013). In 3 volumes. Vol.1. Book. 1. Moscow: Spetskniga. 880 p. 